\title{
Media Pembelajaran Daring Interaktif Berbasis Power Point Dengan Fungsi Hyperlink
}

\section{Putu Desta Pramesti* ${ }^{*}$, Ketut Dibia², Putu Rahayu Ujianti3}

1,2,3 Universitas Pendidikan Ganesha, Singaraja, Indonesia

\section{ARTICLE INFO \\ Article history: \\ Received May 20, 2021 \\ Revised May 22, 2021 \\ Accepted July 04, 2021 \\ Available online July 25, 2021 \\ Kata Kunci: \\ Power Point, Hyperlink, IPA \\ Keywords: \\ Power Point, Hyperlink, IPA

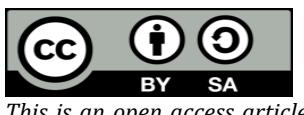 \\ This is an open access article under the CC BY-SA license. \\ Copyright (C) 2021 by Author. \\ Published by Universitas Pendidikan Ganesha.}

\begin{abstract}
A B S T R A K
Pembelajaran daring yang monoton membuat siswa bosan dalam mengikuti pembelajaran. Oleh karena itu, diperlukan suatu media yang cocok untuk menindaklanjuti hal tersebut salah satunya adalah media pembelajaran daring interaktif berbasis power point dengan fungsi hyperlink. Penelitian pengembangan ini bertujuan untuk menghasilkan media pembelajaran daring interaktif berbasis Power Point dengan fungsi Hyperlink pada mata pelajaran IPA materi Rotasi Revolusi Bumi dan Bulan. Penelitian ini dilaksanakan dengan model pengembangan ADDIE. Subjek penelitian ini adalah 1 orang ahli materi, 1 orang ahli media, 1 orang ahli praktisi, dan 3 orang siswa. Sedangkan objek penelitian ini adalah validitas dari media pembelajaran yang telah dikembangkan. Metode pengumpulan data yang digunakan adalah metode observasi, metode wawancara, dan metode kuisioner. Data yang diperoleh kemudian dianalisis untuk mengetahui validitas produk yang dikembangkan. Uji ahli isi materi pembelajaran memperoleh persentase 94\%, uji ahli desain media pembelajaran memperoleh persentase 90\%, uji respon pendidik memperoleh persentase 90\%, dan uji coba perorangan memperoleh rata-rata persentase 94,7\%. Adapun hasil analisis data tersebut memperoleh kualifikasi sangat baik. Berdasarkan hal itu, maka media pembelajaran yang dikembangkan dinyatakan layak digunakan dalam pembelajaran.
\end{abstract}

\section{A B S T R A C T}

Monotonous online learning makes students bored in participating in learning. Therefore, we need a suitable media to follow up on this, one of which is interactive online learning media based on power point with hyperlink function. This development research aims to produce an interactive online learning media based on Power Point with the Hyperlink function in the science subject matter of Earth and Moon Revolution Rotation. This research was carried out using the ADDIE development model. The subjects of this study were 1 material expert, 1 media expert, 1 practitioner expert, and 3 students. While the object of this research is the validity of the learning media that has been developed. The data collection method used is the observation method, the interview method, and the questionnaire method. The data obtained were then analyzed to determine the validity of the developed product. The learning material content experts get a percentage of $94 \%$, the learning media design experts get a percentage of $90 \%$, the teacher response assessment get a percentage of $90 \%$, and the individual trial assessment obtained average percentage of $94.7 \%$. The results of the data analysis obtained very good qualifications. Based on this, the learning media developed is declared suitable for use in learning.

\section{PENDAHULUAN}

Pandemi Covid-19 telah melanda seluruh dunia termasuk juga Indonesia. Kondisi ini membuat pemeritah diharuskan untuk memberlakukan kebijakan-kebijakan baru terhadap seluruh aspek kegiatan masyarakat, salah satunya yakni pada pelaksanaan sistem pembelajaraan. Dalam usaha untuk membatasi penyebaran virus, pemerintah mengeluarkan kebijakan terhadap pelaksanaan sistem pembelajaran, yaitu beralih dari pembelajaran tatap muka menjadi daring (dalam jaringan) (Jamaluddin et al., 2020; Saefulmilah \& Saway, 2020). Pembelajaran daring menjadi satu-satunya solusi dalam sektor pendidikan untuk menanggapi pandemi Covid-19 (Tang et al., 2021). Upaya ini diharapkan mampu memfasilitasi proses pembelajaran supaya tetap bisa berlangsung walaupun ditengah situasi pandemi (Pakpahan \& Fitriani, 2020). Tidak adanya pembelajaran online dapat memperburuk situasi secara global (Jogezai et al., 2021). Pembelajaran daring diberlakukan untuk setiap jenjang pendidikan termasuk didalamnya adalah jenjang sedolah dasar. Setiap muatan pembelajaran dibelajarakan secara daring begitu pula dengan muatan IPA. Meskipun pembelajaran dilakukan secara daring, tetap saja proses pembelajaran muatan IPA hendaknya berpusat pada siswa (student centered) (Muna, 2017). Hal ini bertujuan untuk menyiapkan siswa agar memiliki kompetensi yang baik dan melek sains serta teknologi, serta mampu berpikir logis, 
kritis, kreatif, berargumentasi secara benar, dapat berkomunikasi dan berkolaborasi (Yuliati, 2017). Lebih lanjut, dijelakan bahwa pembelajaran IPA yang berpusat pada siswa akan membawa dampak positif terhadap pertumbuhan kreativitas dan motivasi siswa dalam belajar (Huang et al., 2020). Salah satu upaya untuk mengoptimalkan preses pembelajaran yang berpusat pada siswa adalah dengan memanfaatkan penggunaan media dalam pembelajaran. Media pembelajaran merupakan sebuah alat untuk memudahkan penyampaian pesan yang bersifat abstrak menjadi lebih konkret, sehingga keberadaan media dalam pembelajaran adalah suatu hal yang sangat penting (Prayitno \& Faizah, 2019).

Namun yang terjadi selama berlangsungnya pelaksanaan pembelajaran daring, justru banyak guru yang melaksanakan pembelajaran IPA tanpa memanfaatkan media pembelajaran interaktif, tetapi hanya mengandalkan pemberian materi pembelajaran dan pemberian tugas-tugas yang terdapat pada buku LKS (Lembar Kerja Siswa) saja, yang tentunya sangatlah terbatas. Begitu juga dengan pelaksanaan pembelajaran IPA yang terjadi pada siswa kelas VI di MIN 5 Jembrana. Para siswa hanya ditugaskan untuk membaca materi pembelajaran yang terdapat pada buku LKS dan dilanjutkan dengan mengerjakan tugastugas yang terdapat juga pada buku LKS tersebut. Kegiatan pembelajaran yang demikian tentunya sangat monoton dan membosankan bagi para siswa, karena siswa tidak turut aktif dalam pembelajaran sehingga nantinya akan berdampak negatif terhadap ketercapaian tujuan pembelajaran yang diperoleh siswa. Beberpa penelitian juga memaparkan hal yang hampir sama, yaitu penyebab belum optimalnya hasil belajar IPA di SD karena siswa belum terlibat secara maksimal dalam proses pembelajaran dan kurangnya penggunaan media yang mampu meningkatkan minat belajar siswa (Antari et al., 2019; Hastuti et al., 2019; Lestari, 2018). Selain itu, pelaksanaan pembelajaran daring dikatakan masih belum efektif (Hong et al., 2021). Lebih lanjut dijelaskan, hal ini terjadi guru mengalami kesulitan dalam memilih dan menggunakan media yang sesuai akibatnya pembelajaran dirasa kurang efektif (Ria Puspita Sari et al., 2021; Setiawan et al., 2021; Nopiyanto et al., 2020). Permasalahan ini harus segera ditangani, apabila tidak hal ini akan berpengaruh pada rendahnya ketercapaian tujuan pembelajaran muatan IPA itu sendiri.

Alternatif yang dapat diupayakan dalam hal menangani permasalahan di atas adalah mengembangkan media pembelajaran yang sesuai dengan karakteristik siswa, topik bahasan, dan tentunya situasi serta kondisi. Dengan tersedianya media pembelajaran interaktif, maka diharapkan pembelajaran daring akan berlangsung secara efektif, efisien, dan bermakna bagi para siswa. Media pembelajaran daring interaktif berbasis Power Point dengan fungsi Hyperlink untuk mata pelajaran IPA dengan topik Pengertian dan Akibat dari Rotasi Revolusi Bumi dan Bulan adalah media yang belum ada dan perlu dikembangkan di MIN 5 Jembrana. Power Point merupakan sebuah aplikasi yang sangat baik dalam menyajikan sebuah materi presentasi karena dapat mengolah teks, gambar, warna, tampilan, dan animasi-animasi yang dapat disesuaikan dengan kebutuhan siswa (Astawa \& Tegeh, 2019). Pengoptimalan hasil belajar juga bisa diwujudkan dengan memanfaatkan kemajuan teknologi (Tuma, 2021; Chauhan, 2017). Beberapa kelebihan dari power point yaitu menarik, merangsang siswa, tampilan visual mudah dipahami, memudahkan guru, bersifat kondisional, dan praktis (Wardani et al., 2017). Media pembelajaran power point sangat efektif dalam penyampaian sebuah materi (Astiti et al., 2017). Beberapa penelitian sejatinya telah mengembangkan media berbasis power point dan menyatakan bahwa media ini layak untuk dikembangkan karena mendukung proses pembelajaran menjadi efektif (Putri \& Rezkita, 2019; Wijayanti \& Relmasira, 2019; Permanda et al., 2017). Lebih lanjut, penelitian lain menyebutkan penggunaan media pembelajaran berbasis power point dapat menarik perhatian dan meningkatkan motivasi belajar siswa (Irfan et al., 2019). Namun, dari beberapa penelitian tersebut media yang dikembengkan belum ada yang berisi menu kompetensi, materi pembelajaran, video pembelajaran, ayo berlatih, dan menu evaluasi. Oleh karena itu, pada penelitian ini dikembangkan media pembelajaran daring interaktif berbasis power point yang memanfaatkan fungsi hyperlink dalam setiap slide-nya dan menu evaluasi yang langsung terhubung dengan google form. Tujuan penelitian ini adalah untuk menghasilkan media yang teruji validitasnya, selain itu diharapkan media ini bisa memberikan dampak positif terhadap peningkatan hasil IPA belajar siswa.

\section{METODE}

Penelitian ini merupakan penelitian dan pengembangan (research and development). Adapun fokus dalam penelitian ini yaitu penelitian pengembangan media pembelajaran interaktif berbasis Power Point dengan fungsi Hyperlink pada mata pelajaran IPA. Model pengembangan yang diterapkan pada penelitian ini yaitu menggunakan model pengembangan ADDIE. Model pengembangan ADDIE (Analysis, Design, Development, Implementation, Evaluation) merupakan salah satu model desain pembelajaran yang sistematik. Tahap analysis pada penelitian ini dilakukan dengan menganalisis kebutuhan untuk menentukan permasalahan yang terjadi dan menentukan solusi yang tepat untuk diberikan. Dalam menganalisis kebutuhan, maka terlebih dahulu peneliti perlu melakukan analisis terhadap kurikulum, 
silabus, materi pembelajaran, dan tujuan pembelajaran, melakukan analisis terhadap media pembelajaran yang digunakan oleh guru, melakukan analisis terhadap tingkat ketercapaian tujuan pembelajaran yang dicapai oleh para siswa, serta melakukan analisis terhadap efektivitas sistem pembelajaran yang telah terlaksana. selanjutnya pada tahap design peneliti melakukan rancangan solusi yang akan diberikan berdasarkan analisis kebutuhan, yaitu berupa media pembelajaran daring interaktif berbasis Power Point dengan fungsi Hyperlink. Peneliti dapat melakukan rancangan terhadap unsur-unsur yang terdapat dalam media pembelajaran, meliputi materi pembelajaran IPA untuk kelas VI, tampilan media pembelajaran, objek-objek berupa video dan gambar yang akan disisipkan, dan cara penggunaan media pembelajaran.

Tahap development peneliti mengembangkan solusi yang telah dirancang, yaitu berupa media pembelajaran. Peneliti mengembangkan media pembelajaran sesuai dengan rancangan yang telah dilakukan. Kemudian media pembelajaran yang telah dikembangkan, perlu untuk dievaluasi terlebih dahulu sebelum diimplementasikan. Evaluasi yang dimaksud adalah evaluasi formatif oleh para ahli yang bertujuan untuk merevisi media pembelajaran yang telah dikembangkan. Pada tahap Implementation peneliti mengimplementasikan atau mengujicobakan media pembelajaran yang telah dikembangkan dan telah direvisi kepada sekolah yang dituju untuk diujicobakan kepada para siswa. Namun karena saat ini setiap sekolah menerapkan sistem pembelajaran daring, maka peneliti dapat memberikan media pembelajaran yang telah dikembangkan dan telah direvisi tersebut kepada Wali Kelas. Kemudian, nantinya Wali Kelas yang akan membagikan kepada para siswa pada saat pelaksanaan kegiatan pembelajaran daring. Sedangkan pada tahap evaluation peneliti melakukan evaluasi terhadap media pembelajaran yang telah dikembangkan. Tahap evaluasi ini sebenarnya juga dapat terjadi pada tahapan lainnya. Artinya dalam setiap tahapan sebelumnya, tahap evaluasi dapat dilakukan oleh peneliti.

Subjek pada penelitian ini adalah 1 orang ahli materi, 1 orang ahli media, 1 orang ahli praktisi, dan 3 orang siswa. Sedangkan objek penelitian ini adalah validitas dari media pembelajaran yang telah dikembangkan. Selanjutnya metode pengumpulan data yang digunakan pada penelitian ini adalah metode observasi, metode wawancara, dan metode kuesioner. Metode observasi dilakukan guna untuk mengetahui mengenai keadaan, kendala, dan permasalahan yang dihadapi oleh sekolah penelitian. Metode wawancara dilakukan dengan cara dialog secara langsung. Dalam wawancara yang dilakukan, diajukan pertanyaan-pertanyaan untuk mendapatkan informasi mengenai kebutuhan atau masalah yang dihadapi terhadap sarana dan prasarana yang digunakan oleh guru dalam proses pelaksanaan pembelajaran daring. Sedangkan metode kuesioner digunakan untuk mengumpulkan data mengenai validitas media pembelajaran yang telah dikembangkan yang diperoleh dari ahli isi materi pembelajaran, ahli desain media pembelajaran, respon pendidik, dan uji coba perorangan. Instrumen yang digunakan dalam penelitian ini adalah instrumen angket. Adapun kisi-kisi lembar validasi media pembelajaran dapat dilihat pada Tabel 1.

Tabel 1. Kisi-Kisi Instrumen Ahli Isi Materi Pembelajaran

\begin{tabular}{clccc}
\hline No & \multicolumn{1}{c}{ Aspek Pengkajian } & $\begin{array}{c}\text { Jumlah } \\
\text { Butir }\end{array}$ & No. Butir & $\begin{array}{c}\text { Bentuk } \\
\text { Instrumen }\end{array}$ \\
\hline 1 & Ketepatan KD, KI dan tujuan & 3 & $1,2,3$ & \\
2 & Kesesuaian indikator dan tujuan & 1 & 4 & \\
3 & Kesesuaian tujuan dan materi & 1 & 5 & \\
4 & Kejelasan penyajian materi & 1 & 6 & \\
5 & Kelengkapan materi dan keluesan materi & 2 & 7,8 & \\
6 & Kejelasan bahasa yang digunakan & 1 & 9 & Skala Likert \\
7 & Kejelasan contoh yang digunakan & 1 & 10 & \\
8 & Ketepatan pemilihan gambar, animasi dan video & 3 & $11,12,13$ & \\
9 & Kejelasan informasi pada gambar dan video & 3 & $14,15,16$ & \\
10 & Kecukupan latihan soal dan kesesuaian soal & 2 & 17,18 & \\
11 & Pemberian umpan balik & 1 & 19 & \\
12 & Kesesuaian tes evaluasi & 1 & 20 & \\
\hline
\end{tabular}

Tabel 2. Kisi-Kisi Instrumen Ahli Desain Media Pembelajaran

\begin{tabular}{clccc}
\hline No & \multicolumn{1}{c}{ Aspek Pengkajian } & $\begin{array}{c}\text { Jumlah } \\
\text { Butir }\end{array}$ & No. Butir & $\begin{array}{c}\text { Bentuk } \\
\text { Instrumen }\end{array}$ \\
\hline 1 & Kejelasan judul media pada cover & 1 & 1 & \\
2 & Kejelasan petunjuk penggunaan & 1 & 2 & Skala Likert \\
3 & Kemenarikan tampilan slide & 1 & 3 & \\
\hline
\end{tabular}




\begin{tabular}{clccc}
\hline No & \multicolumn{1}{c}{ Aspek Pengkajian } & $\begin{array}{c}\text { Jumlah } \\
\text { Butir }\end{array}$ & No. Butir & $\begin{array}{c}\text { Bentuk } \\
\text { Instrumen }\end{array}$ \\
\hline 4 & Ketepatan letak teks, gambar, animasi, video & 4 & $4,5,6,7$ \\
5 & Kualitas gambar dan animasi & 2 & 8,9 & \\
6 & Kualitas audio dan gambar pada video & 2 & 10,11 & \\
7 & Kemenarikan background & 1 & 12 & \\
8 & Kesesuaian paduan warna & 1 & 13 & \\
9 & Kesesuaian jenis huruf dan ukuran huruf & 2 & 14,15 \\
10 & Kejelasan bacaan teks dan bahasa & 2 & 16,17 \\
11 & Kemenarikan tampilan slide latihan soal & 1 & 18 \\
12 & Kemenarikan tampilan slide umpan balik & 1 & 19 \\
13 & Kemudahan jangkauan terhadap tes evaluasi & 1 & 20 & (Dimodifikasi dari Agung, 2014)
\end{tabular}

Tabel 3. Kisi-Kisi Instrumen Respon Pendidik atau Praktisi

\begin{tabular}{clccc}
\hline No & \multicolumn{1}{c}{ Aspek Pengkajian } & $\begin{array}{c}\text { Jumlah } \\
\text { Butir }\end{array}$ & No. Butir & $\begin{array}{c}\text { Bentuk } \\
\text { Instrumen }\end{array}$ \\
\hline 1 & Kejelasan petunjuk penggunaan & 1 & 1 & \\
2 & Keterhubungan KD, indikator, tujuan, dan materi & 1 & 2 & \\
3 & Kemenarikan tampilan slide dan warna & 2 & 3,4 & \\
4 & Kemenarikan background & 1 & 5 & \\
5 & Kejelasan penyajian materi & 1 & 6 & \\
6 & Kelengkapan materi dan keluasan materi & 2 & 7,8 & \\
7 & Kejelasan contoh yang digunakan & 1 & 9 & Skala Likert \\
8 & Kejelasan bahasa yang digunakan & 1 & 10 & \\
9 & Ketepatan pemilihan video & 1 & 11 & \\
10 & Kualitas audio dan gambar pada video & 2 & 12,13 & \\
11 & Kejelasan informasi pada video & 1 & 14 & \\
12 & Kejelasan bacaan teks pada slide & 1 & 15 & \\
13 & Kecukupan dan kesesuaian latihan soal & 2 & 16,17 & \\
14 & Kesesuaian tes evaluasi & 1 & 18 & \\
15 & Kemudahan jangkauan terhadap tes evaluasi & 1 & 19 & \\
16 & Kemudahan cara penggunaan media bagi siswa & 1 & 20 & \\
\hline & & & & (Dimodifikasi dari Agung, 2014)
\end{tabular}

Tabel 4. Kisi-Kisi Instrumen Uji Coba Perorangan

\begin{tabular}{clccc}
\hline No & \multicolumn{1}{c}{ Aspek Pengkajian } & $\begin{array}{c}\text { Jumlah } \\
\text { Butir }\end{array}$ & No. Butir & $\begin{array}{c}\text { Bentuk } \\
\text { Instrumen }\end{array}$ \\
\hline 1 & Kejelasan petunjuk penggunaan & 1 & 1 & \\
2 & Kemenarikan tampilan slide & 1 & 2 & \\
3 & Kejelasan bacaan teks pada tampilan slide & 1 & 3 & \\
4 & Kemenarikan pemilihan warna yang digunakan & 1 & 4 & \\
5 & Ketersediaan gambar, animasi, dan video & 3 & $5,6,7$ & \\
6 & Kualitas audio dan gambar pada video & 2 & 8,9 & Skala Likert \\
7 & Kejelasan penyajian materi & 1 & 10 & \\
8 & Kelengkapan materi & 1 & 11 & \\
9 & Kejelasan contoh yang digunakan & 1 & 12 & \\
10 & Kejelasan bahasa yang digunakan & 1 & 13 & \\
11 & Kesesuaian latihan soal & 1 & 14 & \\
12 & Kesesuaian tes evaluasi & 1 & 15 & \\
\hline
\end{tabular}

(Dimodifikasi dari Agung, 2014)

Instrumen yang telah disusun selanjutnya dilakukan tahap uji validitas. Uji validitas dilakukan untuk mengetahui tingkat kevalidan instrumen tersebut dengan menggunakan rumus Gregory. Setelah data terkumpul dengan menggunakan instrumen tersebut, selanjunya akan dilakukan analisis data dengan teknik analisis deskriptif kualitatif dan analisis deskriptif kuantitatif. Data kualitatif merupakan 
data yang diperoleh pada tahap review ahli berupa saran dan komentar, selanjutnya dari data tersebut dilakukan perbaikan terhadap media yang dikembangkan sesuai dengan saran dan komentar yang diberikan sehingga menjadi media yang lebih baik lagi. Sedangkan data kuantitatif merupakan data yang diperoleh pada tahap review ahli berupa skor pada lembar penilaian, kemudian data tersebut dihitung rata-ratanya dengan menggunakan rumus mean guna mendapatkan hasil validitas dari media yang dikembangkan. Setelah rata-ratanya diperoleh selanjutnya dikonversikan dengan tabel konversi tingkat pencapaian skala 5.

\section{HASIL DAN PEMBAHASAN}

\section{Hasil}

Penelitian ini bertujuan untuk menghasilkan media pembelajaran daring interaktif berbasis Power Point dengan fungsi Hyperlink pada mata pelajaran IPA materi Rotasi Revolusi Bumi dan Bulan yang dikembangkan berdasarkan analisis kebutuhan. Media yang dikembangkan pada penelitian ini menggunakan model ADIEE. Adapun hasil yang didapat pada penelitian ini dapat dipaparkan sebagai berikut.

\section{Tahap 1: Analysis (Analisis)}

Analisis kebutuhan ini dilaksanakan melalui wawancara langsung dengan wali kelas VI sekaligus guru mata pelajaran IPA. Hasil dari wawancara tersebut diperoleh data bahwa selama adanya pandemi Covid-19, kegiatan belajar mengajar secara keseluruhan dilaksanakan secara daring melalui Grup WhatsApp. Adaptasi terhadap pelaksanaan pembelajaran daring dirasa cukup sukar untuk dilakukan, hal ini dikarenakan terbatasnya penerapan beberapa komponen pembelajaran, seperti terbatasnya penggunaan metode pembelajaran yang dapat diterapkan dalam pembelajaran daring, serta kurangnya inovasi dan kemampuan guru yang masih rendah dalam menentukan dan menerapkan media pembelajaran interaktif untuk pembelajaran daring. Pemberian materi pembelajaran dan pemberian tugas-tugas yang diberikan guru kepada siswa hanya mengandalkan buku LKS (Lembar Kerja Siswa) yang telah dimiliki oleh masing-masing siswa dirumah. Proses komunikasi, diskusi, dan tanya jawab antara guru dan siswa dilaksanakan melalui Grup Whatsapp yang tersedia. Kondisi pelaksanaan pembelajaran yang demikian tentunya sangat monoton dan membosankan bagi para siswa, karena siswa tidak turut aktif dalam pembelajaran sehingga nantinya akan berdampak negatif terhadap ketercapaian tujuan pembelajaran yang diperoleh siswa, khususnya pada mata pelajaran IPA. Untuk mengatasi hal tersebut, maka dicarikan sebuah solusi yaitu dengan mengembangkan media pembelajaran yang dapat digunakan dalam pelaksanaan pembelajaran daring. Media pembelajaran yang dikembangkan harus mampu memuat materi pembelajaran, latihan soal, dan evaluasi pembelajaran yang lengkap, terperinci, dan menarik bagi siswa. Media pembelajaran yang dikembangkan yaitu media pembelajaran daring interaktif berbasis Power Point dengan fungsi Hyperlink. Proses mengidentifikasi materi pembelajaran dilakukan dengan menentukan Kompetensi Dasar dan Indikator. Berdasarkan analisis kebutuhan di lapangan dan karakteristik siswa, maka ditentukan Kompetensi Dasar dan Indikator seperti tabel 5

Tabel 5. Kompetensi Dasar dan Indikator

\begin{tabular}{|c|c|}
\hline Kompetensi Dasar & Indikator \\
\hline \multirow{4}{*}{$\begin{array}{l}\text { 3.8 Menjelaskan peristiwa rotasi dan revolusi } \\
\text { bumi serta terjadinya gerhana bulan dan } \\
\text { gerhana matahari. }\end{array}$} & $\begin{array}{l}\text { Mendeskripsikan peristiwa } \\
\text { revolusi bumi }\end{array}$ \\
\hline & $\begin{array}{l}\text { 3.8.2 Mendeskripsikan peristiwa rotasi } \\
\text { revolusi bulan. }\end{array}$ \\
\hline & $\begin{array}{l}\text { 3.8.3 Menjelaskan akibat yang ditimbulkan dari } \\
\text { peristiwa rotasi dan revolusi bumi. }\end{array}$ \\
\hline & $\begin{array}{l}\text { 3.8.4 Menjelaskan akibat yang ditimbulkan dari } \\
\text { peristiwa rotasi dan revolusi bulan. }\end{array}$ \\
\hline
\end{tabular}

\section{Tahap 2: Design (Perancangan)}

Setelah melaksanakan tahap analisis terhadap beberapa aspek data yang diperlukan, maka tahap berikutnya adalah tahap design (perancangan). Pada tahap ini dilakukan penentuan terhadap komponen yang akan dimuat dalam media pembelajaran, seperti rumusan tujuan pembelajaran, cakupan materi pembelajaran, soal-soal latihan, tes evaluasi pembelajaran, gambar dan animasi pendukung materi pembelajaran, video pembelajaran, serta komponen lainnya yang mendukung pengembangan media pembelajaran. Segala komponen yang akan termuat pada media pembelajaran yang dikembangkan harus diperhatikan dengan baik agar media pembelajaran tersebut dapat mencapai tujuan dari penelitian 
pengembangan yang dilakukan. Pembuatan storyboard juga dilakukan untuk mempermudah perancangan pengembangan media pembelajaran.

\section{Tahap 3: Development (Pengembangan)}

Pada tahap development dilakukan pengembangan produk dari rancangan desain yang telah dibuat sebelumnya untuk menghasilkan produk media pembelajaran daring interaktif berbasis Power Point dengan fungsi Hyperlink. Kegiatan pertama yang dilakukan adalah pengumpulan komponen yang akan dimuat dalam media pembelajaran, seperti materi pembelajaran, soal-soal latihan, tes evaluasi pembelajaran, gambar dan animasi pendukung materi pembelajaran, serta video pembelajaran. Materi pembelajaran, soal-soal latihan, dan tes evaluasi pembelajaran diperoleh dari buku siswa dan buku guru Tema 8 kelas VI, buku LKS Tematik kelas VI, dan buku sekolah elektronik mata pelajaran IPA kelas VI. Sementara itu, gambar dan animasi pendukung materi pembelajaran, serta video pembelajaran didapatkan dari buku sekolah elektronik mata pelajaran IPA kelas VI, Google Search, dan Youtube. Setelah media pembelajaran selesai dikembangkan, maka selanjutnya merancang instrumen untuk mengetahui validitas dari media pembelajaran tersebut. Validitas ini dapat diketahui melalui validasi oleh para ahli, penilaian respon pendidik, dan penilaian uji coba perorangan. Adapun beberapa tampilan proses pengembangan media pembelajaran daring interaktif berbasis Power Point dengan fungsi Hyperlink, seperti ditunjukkan pada gambar 1 .

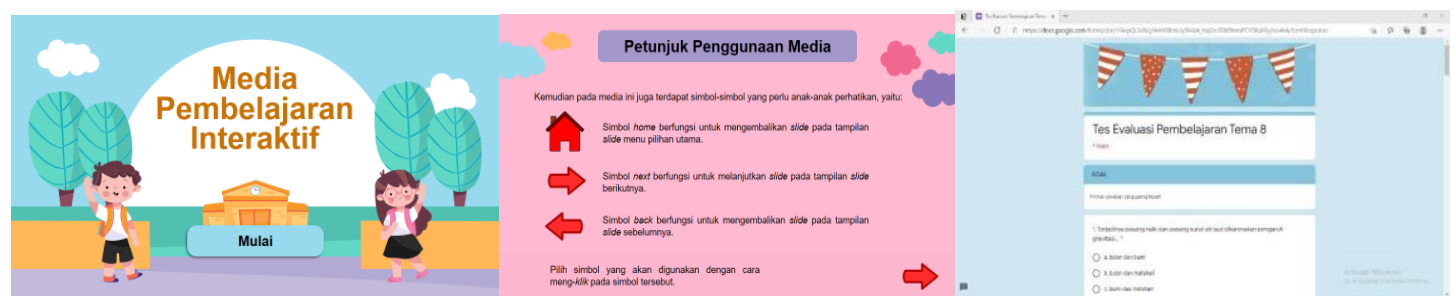

Gambar 1. Tampilan media yang telah dikembangkan

Setelah dikembangkan, untuk mengetahui Validitas pada media pembelajaran daring interaktif berbasis Power Point dengan fungsi Hyperlink dapat diketahui melalui validasi oleh ahli isi materi pembelajaran dan ahli desain media pembelajaran, penilaian respon pendidik, dan penilaian uji coba perorangan. Hasil Penilaian Ahli Isi Materi Pembelajaran pada media pembelajaran daring interaktif berbasis Power Point dengan fungsi Hyperlink yang telah dikembangkan dinilai oleh ahli isi materi pembelajaran mendapatkan nilai persentase berada pada tingkat pencapaian rentangan 90-100 dengan kualifikasi sangat baik, sehingga media pembelajaran daring interaktif berbasis Power Point dengan fungsi Hyperlink tidak perlu direvisi. Hasil Penilaian Ahli Desain Media Pembelajaran pada media pembelajaran daring interaktif berbasis Power Point dengan fungsi Hyperlink yang telah dikembangkan dinilai oleh ahli isi media pembelajaran mendapatkan nilai persentase berada pada tingkat pencapaian rentangan 90-100 dengan kualifikasi sangat baik, sehingga media pembelajaran daring interaktif berbasis Power Point dengan fungsi Hyperlink tidak perlu direvisi. Hasil Penilaian Respon Pendidik mendapatkan nilai persentase berada pada tingkat pencapaian rentangan 90-100 dengan kualifikasi sangat baik, sehingga media pembelajaran daring interaktif berbasis Power Point dengan fungsi Hyperlink tidak perlu direvisi. Selanjutnya Hasil Penilaian Uji Coba Perorangan mendapatkan nilai persentase berada pada tingkat pencapaian rentangan 90-100 dengan kualifikasi sangat baik, sehingga media pembelajaran daring interaktif berbasis Power Point dengan fungsi Hyperlink tidak perlu direvisi.

\section{Tahap 4: Implementation (Implementasi)}

Pada tahap implementation dilakukan implementasi terhadap media pembelajaran yang telah dikembangkan, yaitu media pembelajaran daring interaktif berbasis Power Point dengan fungsi Hyperlink dalam pembelajaran. Implementasi ini dilakukan untuk mengetahui penilaian dari para responden terhadap media pembelajaran yang telah dikembangkan berdasarkan indikator-indikator yang dinilai pada instrumen penilaian yang telah disusun. Pada tahap implementation ini dilakukan beberapa hal diantaranya adalah sebagai berikut. Uji validitas produk media pembelajaran daring interaktif berbasis Power Point dengan fungsi Hyperlink oleh para ahli, yaitu dan ahli desain media pembelajaran. Uji respon pendidik oleh guru mata pelajaran IPA untuk mengetahui penilaian guru terhadap media pembelajaran dari segi isi materi pembelajaran, desain media pembelajaran, dan kemudahan penggunaan media pembelajaran. Uji coba perorangan oleh 3 orang siswa kelas VI untuk mengetahui penilaian terhadap kelayakan dan kemudahan penggunaan media pembelajaran dari sudut pandang siswa. 


\section{Tahap 5: Evaluation (Evaluasi)}

Pada tahap evaluation dilakukan evaluasi terhadap media pembelajaran yang telah dikembangkan, yaitu media pembelajaran daring interaktif berbasis Power Point dengan fungsi Hyperlink. Evaluasi terhadap media pembelajaran dalam penelitian ini dilakukan berdasarkan evaluasi formatif yang diberikan oleh ahli isi materi pembelajaran, ahli desain media pembelajaran, respon pendidik, dan uji coba perorangan. Hasil evaluasi berupa penilaian dan revisi yang diberikan oleh para ahli, respon pendidik, dan uji coba perorangan akan diterapkan pada media pembelajaran sebagai acuan dalam memperbaiki dan menyempurnakan media pembelajaran yang telah dikembangkan. Hal ini bertujuan agar media pembelajaran yang dikembangkan menjadi lebih baik kedepannya dan meningkatkan nilai media pembelajaran dalam segala aspek.

\section{Pembahasan}

Penelitian pengembangan ini menghasilkan sebuah produk berupa media pembelajaran daring interaktif berbasis Power Point dengan fungsi Hyperlink pada mata pelajaran IPA kelas VI. Media pembelajaran ini bertujuan sebagai inovasi penggunaan media pembelajaran pada pelaksanaan pembelajaran daring yang sebelumnya tidak diterapkan di sekolah. Kegiatan pembelajaran daring yang dilaksanakan di sekolah dasar sebelumnya tidak memanfaatkan media pembelajaran interaktif, tetapi hanya mengandalkan pemberian materi pembelajaran dan pemberian tugas-tugas yang terdapat pada buku LKS (Lembar Kerja Siswa) yang tentunya sangat terbatas. Kegiatan pembelajaran daring seharusnya dapat berlangsung secara efektif, efisien, dan bermakna bagi siswa guna membantu ketercapaian tujuan pembelajaran oleh para siswa. Kegiatan pembelajaran daring yang demikian dapat terwujud dengan memanfaatkan media pembelajaran interaktif yang dapat menarik minat dan motivasi belajar siswa, khususnya pada mata pelajaran yang membutuhkan pemahaman lebih bagi siswa seperti mata pelajaran IPA. Pembelajaran yang tidak mengunakan suatu model atau strategi akan membuat siswa menjadi cepat jenuh dalam mengikuti proses pembelajaran (Suryantari et al., 2019; Ana, 2018; Elyas, 2018; Surya, 2017). Berdasarkan hasil validitas yang dilakukan oleh para ahli dari media interaktif berbasis Power Point yang direview menyatakan media ini layak/valid untuk digunakan. Hal tersebut dikarenakan penyajian materi dengan video, teks, animasi-animasi dan gambar disajikan dengan baik sehingga menjadi lebih menarik dan dapat menumbuhkan motivasi belajar. Selain itu kualitas dan tampilan media ini yang dikembangkan sudah sesuai dengan syarat-syarat media yang baik, yaitu efektif, efisien, dan komunikatif. Temuan penelitian ini sejalan dengan penelitian yang dilaksanakan oleh Tegeh (2019). Hasil penelitian menyatakan pengembangan media pembelajaran yaitu (a) hasil review ahli isi mata pelajaran menunjukkan produk berpredikat sangat baik (b) hasil review ahli media menunjukkan produk berpredikat sangat baik (c) hasil review ahli desain pembelajaran menunjukkan produk berpredikat sangat baik, (d) hasil uji perorangan menunjukkan produk berpredikat sangat baik, hasil uji kelompok kecil menunjukkan produk berpredikat sangat baik.

Media pembelajaran daring interaktif berbasis Power Point dengan fungsi Hyperlink merupakan media pembelajaran perangkat lunak (software) sehingga tepat dan efektif untuk diterapkan dalam pembelajaran daring. Power Point merupakan program aplikasi untuk membuat atau mengelola data presentasi. Data presentasi yang dibuat dapat berupa teks, tabel, gambar, bagan organisasi, dan sebagainya, (Misbah et al., 2017). Materi pembelajaran yang disajikan dapat dimuat dan diprogram sedemikian rupa sehingga tampilan Power Point tersebut menjadi menarik dan dapat meningkatkan minat, motivasi, dan antusias belajar siswa. Selain itu, power point juga dapat menarik minat siswa untuk fokus belajar dan dapat memperjelas materi pembelajaran sehingga dapat membantu siswa memahami konsep materi pembelajaran dan dapat meningkatkan hasil belajar siswa (Nurhidayati et al., 2019; Elpira \& Ghufron, 2015; Nurhidayati et al., 2019). Power Point layak untuk digunakan sebagai media pembelajaran dengan didukung tampilan dan konten yang baik, sehingga dapat menarik perhatian siswa, mudah dalam penggunaan, dan dapat menyampaikan pesan dengan baik (Gowasa et al., 2019; Susanti et al., 2020). Selain itu, hal tersebut juga sesuai dengan kebutuhan yang ada dalam sekolah dasar. Media power point dapat merangsang siswa untuk mengetahui lebih jauh informasi tentang bahan ajar yang tersaji karena tampilannya yang menarik, dan pesan informasi secara visual mudah dipahami siswa ditambah dengan kelengkapan materi pembelajaran yang dapat disampaikan, (Damitri, 2020; Purwanto et al., 2016).

Berdasarkan hal tersebut, maka media pembelajaran daring interaktif berbasis Power Point dengan fungsi Hyperlink baik untuk diterapkan dalam pelaksanaan pembelajaran daring. Media pembelajaran daring interaktif berbasis Power Point dengan fungsi Hyperlink diyakini dapat meningkatkan minat dan motivasi belajar siswa sehingga pembelajaran daring dapat berlangsung secara efektif, efisien, dan bermakna bagi siswa, serta akan berpengaruh pada tingkat ketercapaian tujuan pembelajaran yang dicapai oleh para siswa. Adapun kelebihan dari media pembelajaran yang 
dikembangkan adalah dapat menyajikan teks, gambar, foto, animasi, audio dan video sehingga lebih menarik, dapat menjangkau kelompok banyak, tempo dan cara penyajian bisa disesuaikan, penyajiannya masih bisa bertatap muka, dan dapat digunakan secara berulang-ulang (Sulaiman, 2020). Adapun kekurangan dalam penelitian yaitu hanya dapat dilaksanakan sampai tahap analisis, perancangan dan pengembangan saja sedangkan tahap implementasi dan evalusi belum dapat dilakukan karena pembelajaran dilakukan dengan proses pembelajaran daring. Harapan peneliti untuk penelitian selanjutnya adalah dengan menyempurnakan penelitian ini atau menuntaskan setiap tahap-tahapan dengan sesuai agar nantinya penelitian sejenisnya bisa dikembangkan dengan sangat maksimal. Adapun saran yang dapat disampaikan berkaitan dengan penelitian pengembangan media pembelajaran daring interaktif berbasis Power Point dengan fungsi Hyperlink adalah sebagai berikut. Kepada siswa dapat menggunakan media pembelajaran daring interaktif berbasis Power Point dengan fungsi Hyperlink pada pelaksanaan pembelajaran daring khususnya pada mata pelajaran. Kepada guru dapat menerapkan media pembelajaran daring interaktif berbasis Power Point dengan fungsi Hyperlink dalam melaksanakan pembelajaran daring khususnya pada mata pelajaran IPA materi Rotasi Revolusi Bumi dan Bulan. Dengan menerapkan media pembelajaran ini guru akan terbantu dalam menjelaskan materi pembelajaran dan memberikan evaluasi pembelajaran kepada para siswa. Adapun Implikasi dari penelitian ini yaitu: Siswa dapat menggunakan media pembelajaran daring interaktif berbasis Power Point dengan fungsi Hyperlink untuk meningkatkan minat dan motivasi belajar siswa serta memudahkan pemahaman siswa terhadap materi pembelajaran. Guru dapat terbantu dalam menjelaskan materi pembelajaran dan memberikan evaluasi pembelajaran kepada siswa saat melaksanakan pembelajaran daring dengan menerapkan media pembelajaran Sekolah dapat menjadikan media pembelajaran daring interaktif berbasis Power Point dengan fungsi Hyperlink sebagai acuan bagi sekolah dalam melaksanakan sistem pembelajaran daring dalam upaya meningkatkan mutu pembelajaran.

\section{SIMPULAN}

Simpulan pada penelitian ini adalah media pembelajaran daring interaktif berbasis Power Point dengan fungsi Hyperlink yang telah dikembangkan memiliki kualifikasi sangat baik. Hal ini ditunjukkan melalui hasil analisis data yang telah dilakukan oleh peneliti sehingga media pembelajaran daring interaktif berbasis Power Point dengan fungsi Hyperlink layak untuk digunakan dalam proses pembelajaran daring.

\section{DAFTAR PUSTAKA}

Agung, A. A. G. (2014). Metodologi Penelitian Pendidikan. Aditya Media Publishing.

Ana, N. Y. (2018). Penggunaan model pembelajaran discovery learning dalam peningkatan hasil belajaran siswa di sekolah dasar. Jurnal Imiah Pendidikan Dan Pembelajaran, 2(1). https://doi.org/http://dx.doi.org/10.23887/jipp.v2i1.13851.

Antari, N. L. G. S., Pudjawan, K., \& Wibawa, I. M. C. (2019). Pengaruh Model Pembelajaran Kooperatif Tipe Course Review Horay Berbantuan Media Gambar Terhadap Hasil Belajar IPA. International Journal of Elementary Education, 3(2), 116-123. http://dx.doi.org/10.23887/ijee.v3i2.18512.

Astawa, P. A., \& Tegeh, I. M. (2019). Pengaruh Model Pembelajaran Kooperatif Tipe Make A Match Berbantuan Media Powerpoint Terhadap Hasil Belajar IPA. Jurnal Ilmiah Sekolah Dasar, 3(1), 98106. http://dx.doi.org/10.23887/jisd.v3i1.17663.

Astiti, N. K. A., Suarjana, I. M., \& Arini, N. W. (2017). Pengaruh Model Pembelajaran VCT Berbantuan Power Point Terhadap Hasil Belajar PKn Kelas V. Mimbar PGSD, 5(2), 1-10. http://dx.doi.org/10.23887/jjpgsd.v5i2.10913.

Chauhan, S. (2017). A meta-analysis of the impact of technology on learning effectiveness of elementary students. Computers \& Education, 105, 14-30. https: //doi.org/10.1016/j.compedu.2016.11.005.

Damitri, D. E. (2020). Keunggulan Media Powerpoint Berbasis Audio Visual Sebagai Media Presentasi Terhadap Hasil Belajar Siswa SMK Teknik Bangunan. Jurnal Kajian Pendidikan Teknik Bangunan, 6(2). https://ejournal.unesa.ac.id/index.php/jurnal-kajian-ptb/article/view/36296.

Elpira, N., \& Ghufron, A. (2015). Pengaruh penggunaan media powerpoint terhadap Minat dan hasil belajar ipa siswa kelas IV SD. Jurnal Inovasi Teknologi Pendidikan, 2(1), 94-104. https://doi.org/10.21831/tp.v2i1.5207.

Elyas, A. H. (2018). Penggunaan Model Pembelajaran E-Learning Dalam Meningkatkan Kualitas Pembelajaran. Warta Dharmawangsa, 56. https://doi.org/10.46576/wdw.v0i56.4.

Gowasa, S., Harahap, F., \& Suyanti, R. D. (2019). Perbedaan penggunaan media powerpoint dan video pembelajaran terhadap kemampuan berpikir tingkat tinggi dan retensi memori siswa pada mata pelajaran IPA di kelas V SD. Jurnal Tematik, 9(1), 19-27. 
https://jurnal.unimed.ac.id/2012/index.php/tematik/article/viewFile/12859/10976.

Hastuti, H. W., Baedowi, S., \& Mushafanah, Q. (2019). Keefektifan Model Pembelajaran Numbered Heads Together Berbantu Media Panelpa (Papan Flanel IPA) Terhadap Hasil Belajar. International Journal of Elementary Education, 3(2), 108-115. https://doi.org/http://dx.doi.org/10.23887/ijee.v3i2.18513.

Hong, J.-C., Lee, Y.-F., \& Ye, J.-H. (2021). Procrastination predicts online self-regulated learning and online learning ineffectiveness during the coronavirus lockdown. Personality and Individual Differences, 1-8. https://doi.org/https://doi.org/10.1016/j.paid.2021.110673

Huang, S.-Y., Kuo, Y.-H., \& Chen, H.-C. (2020). Applying Digital Escape Rooms Infused with Science Teaching in Elementary School: Learning Performance, Learning Motivation, and Problem-Solving Ability. Journal Pre-Proof, 1-46. https://doi.org/10.1016/j.tsc.2020.100681.

Irfan, Muhiddin, \& Ristiana, E. (2019). Pengembangan Media Pembelajaran IPA Berbasis Powerpoint di Sekolah Dasar. Indonesian Journal of Primary Education, 3(2), 16-27. /https://doi.org/10.17509/ijpe.v3i2.21765.

Jamaluddin, D., Ratnasih, T., Gunawan, H., \& Paujiah, E. (2020). Pembelajaran Daring Masa Pandemik Covid-19 Pada Calon Guru: Hambatan, Solusi Dan Proyeksi. LP2M, 1-10. http://digilib.uinsgd.ac.id/30518/.

Jogezai, N. A., Baloch, F. A., Jaffar, M., Shah, T., Khilji, G. K., \& Bashir, S. (2021). Teachers' attitudes towards social media (SM) use in online learning amid the COVID-19 pandemic: the effects of SM use by teachers and religious scholars during physical distancing. Heliyon, 7, 1-9. https://doi.org/10.1016/j.heliyon.2021.e06781.

Lestari, N. P. C. (2018). Penerapan Model Pembelajaran Kooperatif Tipe Nht Berbantuan Media Audio Visual Untuk Meningkatkan Hasil Belajar IPA. Journal of Education Action Research, 2(4), 318325. http://dx.doi.org/10.23887/jear.v2i4.16331.

Misbah, D., Surya, M., \& Maskur, M. (2017). Penggunaan Media Audio Visual dalam Pembelajaran yang Berbasis Power Point Model Pop Up untuk Meningkatkan Hasil Belajar Siswa Pada Materi Kosakata Mata Pelajaran Bahasa Arab. Jurnal Teknologi Pendidikan Dan Pembelajaran, 2(2). https://doi.org/10.31980/tp.v2i2.144.

Muna, I. A. (2017). Model Pembelajaran POE (Predict-Observe-Explain) Dalam Meningkatkan Pemahaman Konsep Dan Keterampilan Proses IPA. El-Wasathiya: Jurnal Studi Agama, 5(1), 73-91. https://media.neliti.com/media/publications/194440-ID.

Nopiyanto, Y. E., Raibowo, S., Suryatama, R. Y., \& Brahim. (2020). Hambatan Guru Pendidikan Jasmani Generasi 80-an Dalam Pembelajaran Daring Di Tengah Pandemi Covid-19. Jurnal Sporta Saintika, 5(2), 139-148. https://doi.org/10.24036/sporta.v5i2.140.

Nurhidayati, N., Asrori, I., Ahsanuddin, M., \& Dariyadi, M. W. (2019). No TitlePembuatan Media Pembelajaran Berbasis Powerpoint Dan Pemanfaatan Aplikasi Android Untuk Guru Bahasa Arab. Jurnal Karinov, 2(3), 181-184. http://dx.doi.org/10.17977/um045v2i3p181-184.

Pakpahan, R., \& Fitriani, Y. (2020). Analisa Pemanfaatan Teknologi Informasi Dalam Pembelajaran Jarak Jauh Di Tengah Pandemi Virus Corona Covid-19. JISAMAR (Journal of Information System, Applied, Management, Accounting and Researh), 4(2). http://journal.stmikjayakarta.ac.id/index.php/jisamar/article/view/181.

Perignat, E., \& Katz-Buonincontro, J. (2019). STEAM in practice and research: An integrative literature review. Thinking Skills and Creativity, 31, 31-43. https://doi.org/doi:10.1016/j.tsc.2018.10.002.

Permanda, S., Alpusari, M., \& Noviana, E. (2017). Pengembangan Media Pembelajaran Berbasis Powerpoint Pada Mata Pelajaran Ipa Kelas IVC SD Negeri 147 Pekanbaru. Jurnal Online Mahasiswa Fakultas Keguruan Dan Ilmu Pendidikan Universitas Riau, 1-13. https://www.neliti.com/publications/189909.

Prayitno, S. H., \& Faizah, H. (2019). Pengembangan Media Pembelajaran untuk Materi FPB dan KPK bagi Siswa Sekolah Dasar Kelas IV. UNION: Jurnal Pendidikan Matematika, 7(3), 317-327. https://core.ac.uk/download/pdf/270259827.pdf.

Purwanto, W., RWW, E. T. D., \& Hariyono, H. (2016). Penggunaan Model Problem Based Learning dengan Media Powerpoint untuk Meningkatkan Minat Belajar Siswa. Jurnal Pendidikan: Teori, Penelitian, Dan Pengembangan, 1(9), 1700-1705.: http://dx.doi.org/10.17977/jp.v1i9.6721.

Putri, F. A. B., \& Rezkita, S. (2019). Pengembangan Media Pembelajaran IPA Berbasis Powerpoint Interaktif Untuk Siswa Kelas V Sekolah Dasar Negeri Gondolayu. Trihayu: Jurnal Pendidikan KeSD-An, 5(3), 684-693. http://dx.doi.org/10.30738/trihayu.v5i3.6122.

Ria Puspita Sari, N., Tusyantari, B., \& Suswandari, M. (2021). Dampak Pembelajaran Daring Bagi Siswa Sekolah Dasar Selama Covid-19. Prima Magistra: Jurnal Ilmiah Kependidikan, 2(1), 9-15. https://doi.org/10.37478/jpm.v2i1.732. 
Saefulmilah, R. M. I., \& Saway, M. H. M. (2020). Hambatan-Hambatan Pada Pelaksanaan Pembelajaran Daring Di SMA Riyadhul Jannah Jalancagak Subang. Nusantara : Jurnal Pendidikan Dan Ilmu Sosial, 2(3), 393-404. https://ejournal.stitpn.ac.id/index.php/nusantara

Setiawan, B., Pramulia, P., Kusmaharti, D., Juniarso, T., \& Wardani, I. S. (2021). Peningkatan Kompetensi Guru Sekolah Dasar Dalam Pengembangan Media Pembelajaran Daring di SDN Margorejo I Kota Surabaya. Jurnal Pengabdian Dan Pemberdayaan Masyarakat, 1(1), 46-57. https://doi.org/10.31331/manggali.v1i1.1547.

Sulaiman, A. (2020). Perbedaan Penggunaan Media Powerpoint Berbasis Hyperlink Vs Media Powerpoint Templete dan Motivasi Belajar Terhadap Hasil Belajar Kognitif. Education Journal: Journal Educational Research and Development, 4(2), 213-220. https://doi.org/10.31537/ej.v4i2.355.

Surya, Y. F. (2017). Penggunaan Model Pembelajaran Pendidikan Karakter Abad 21 pada Anak Usia Dini. Jurnal Obsesi: Jurnal Pendidikan Anak Usia Dini, 1(1), 52-61. https://doi.org/10.31004/obsesi.v1i1.31.

Suryantari, N. M. A., Pudjawan, K., \& Wibawa, I. M. C. (2019). Pengaruh Model Pembelajaran Inkuiri Terbimbing Berbantuan Media Benda Konkret Terhadap Sikap Ilmiah dan Hasil Belajar IPA. International Journal of Elementary Education, 3(3), 316-326. http://dx.doi.org/10.23887/ijee.v3i3.19445.

Susanti, E., Ritonga, M., \& Bambang, B. (2020). Pengaruh Penggunaan Media Powerpoint Terhadap Minat Belajar Bahasa Arab Siswa. Arabiyatuna: Jurnal Bahasa Arab, 4(1), 179-192. http://dx.doi.org/10.29240/jba.v4i1.1406.

Tang, Y. M., Chen, P. C., Law, K. M. Y., Wu, C. H., Lau, U., Guan, J., He, D., \& Ho, G. T. S. (2021). Comparative analysis of Student's live online learning readiness during the coronavirus (COVID-19) pandemic in the higher education sector. Computers \& Education, 168, 1-17. https://doi.org/10.1016/j.compedu.2021.104211.

Tuma, F. (2021). The use of educational technology for interactive teaching in lectures. Annals of Medicine and Surgery 62, 231-235. https: //doi.org/10.1016/j.amsu.2021.01.051.

Wardani, R. F. A. K., Rifai, M., \& Mandalawati, T. K. (2017). Efektivitas Model Pembelajaran Clis Berbantuan Media Slide Powerpoint Terhadap Hasil Belajar IPA. Premiere Educandum: Jurnal Pendidikan Dasar Dan Pembelajaran, 7(2), 104 - 114. https://doi.org/10.25273/pe.v7i2.1596.

Wijayanti, W., \& Relmasira, S. C. (2019). Pengembangan Media PowerPoint IPA Untuk Siswa Kelas IV SD Negeri Samirono. Jurnal Penelitian Dan Pengembangan Pendidikan, 3(2), 77-83. http://dx.doi.org/10.23887/jppp.v3i2.17381.

Yuliati, Y. (2017). Literasi Sains Dalam Pembelajaran IPA. Jurnal Cakrawala Pendas, 3(2), 21-28. http://dx.doi.org/10.31949/jcp.v3i2.592. 